\title{
Proměna prekonceptu žáků 3. třídy základní školy ${ }^{1}$ \\ Transformation of 3rd grade pupil's preconception

\author{
Kateřina Korcová
}

\begin{abstract}
Abstrakt: Př́́spěvek pojednává o vlivu didaktického zpracování učiva a jeho zprostředkování žákům na kvalitu a proměnu jejich prekonceptu v průběhu času. Cílem je zjistit a popsat vliv didaktického zpracování a zprostředkování učiva učitelem na proměnu žákova prekonceptu a na trvalost uchování modifikovaného prekonceptu v jeho paměti. Při sběru dat bylo využito metody pozorování výuky a analýzy žákovy kresby. Didaktické zpracování učiva bylo hodnoceno na základě počtu konstruktivistických znaků vyskytujících se ve výuce, přičemž rozhodující byl vliv jejich aplikace na kvalitu a proměnu prekonceptu žáků. Bylo zjištěno, že př́tomnost jistých konstruktivistických znaků výsledky žáků ovlivňuje.
\end{abstract}

Klíčová slova: konstruktivismus ve výuce, tradiční pojetí výuky, prekoncept, primární vzdělávání, pozorování výuky, analýza žákovské kresby

\begin{abstract}
Contribution deals with the influence of didactic processing of the subject matter and its intermediation to the pupils on quality and transformation of pupil's preconception during the time. Two research methods were applied for collecting data - the observation was focused on whether the teacher uses the constructivist approach during the lessons or not, the data from children were collected in form of drawings. The analysis of the data about teacher's concept of schooling and the analysis of pupil's drawings showed which characteristics of constructivist approach were used in the lesson and how they influenced the quality and transformation of children's preconceptions. It was found out that some of the constructivist characteristics had an influence on the quality and transformation of the pupil's preconceptions.
\end{abstract}

Keywords: constructivism in education, traditional education, preconception, primary education, observation in the lesson, pupil's drawing analysis

\section{1 Úvod}

Inspirací pro výzkum prekonceptů žáků 3. třídy základní školy byla probíhající reforma vzdělávání. Provedené šetření se zaměřilo na vliv konstruktivistických prvků výuky na proměnu a trvalost prekonceptu žáků. Cílem bylo zjistit a popsat vliv didaktického zpracování a zprostředkování učiva učitelem na proměnu žákova prekonceptu a na trvalost uchování modifikovaného prekonceptu v žákově paměti. Ke sběru dat o didaktickém zpracování učiva učiteli byla využita metoda pozorování. Žákům byl rozdán pracovní list s testovou otázkou zjišt’ující kvalitu jejich prekonceptu, a to ve třech fázích. Společné téma, na kterém byly dané

\footnotetext{
${ }^{1}$ Prezentované téma bylo zpracováno v rámci disertační práce obhájené v dubnu 2011.
} 
kategorie zjišt'ovány, představovala pro všechny zkoumané subjekty trávicí soustava člověka. Vše bylo sledováno na pozadí tradiční a konstruktivistické teorie vzdělávání.

\section{Teorie vzdělávání}

V českém školství se nyní můžeme setkat se dvěma hlavními směry v oblasti vzdělávacích teorií, které stojí do značné míry v protikladu. Jedná se o směr tzv. tradiční, zakotvený historicky, a konstruktivistický, který je reakcí na nedokonalosti teorie tradiční založené, na zásadách behaviorismu. Rozdíl mezi oběma proudy je mimo jiné možné spatřovat ve filozofickém názoru na to, zda je možné poznávat realitu takovou, jaká je, nebo zda dochází ke zkreslením a čím jsou tato zkreslení způsobena.

Jako tradiční se označuje vzdělávací teorie, kterou lze charakterizovat jako materiální, tedy založenou převážně na nutnosti osvojit si vzdělávací obsah v podobě encyklopedických znalostí (Klafki, 1967, s. 32). Einsiedler (2005, s. 383) vidí tradiční teorie jako teorie instruktivní, založené na převážné aktivitě vzdělávajícího a vychovávajícího jedince při působení na jedince vzdělávaného a vychovávaného.

Konstruktivismus můžeme zařadit mezi teorie formálního vzdělávání, protože kromě předávání a učení se poznatkům věd klade důraz i na samotnou schopnost poznávat a na rozvoj žákovy osobnosti, procesů myšlení, tvořivosti a dalších schopností a dovedností, které nejsou bezprostředně vázány na encyklopedické informace. Einsiedler (2005, s. 383) hovoří o protikladu $\mathrm{k}$ teoriím instruktivním, které kladou ve výchovně vzdělávacím procesu důraz na roli učitele - instruktora, nikoli žáka.

\section{Sběr dat}

Výzkumný vzorek tvořilo 21 školních tříd. Analyzovány byly práce od 331 žáka. Všichni žáci byli ze třetích tříd základních škol. Výzkum probíhal na jaře v letech 2006 a 2008 ve třech fázích. Nejprve byl zjišstován prekoncept žáků, poté proběhlo pozorování ve výuce s následným zjišt'ováním modifikovaného prekonceptu a v poslední fázi bylo ověřováno, $\mathrm{k}$ jakému $\mathrm{z}$ dřive zjištěných prekonceptů se žáci po čase více blíží. Byla zvolena kombinace metod testu a pozorování výuky s následným zápisem do záznamového archu. Důvodů pro výběr právě těchto metod bylo několik. Pro sledování výkonu žáků představuje test metodu, která je pro žáky nenáročná na splnění. Pro badatele je poměrně snadné získat a vyhodnotit testová data od velkého množství respondentů.

Pozorování výuky je metoda, která relativně málo zatěžuje učitele. Zatímco přítomnost záznamového zařízení je vnímána jako rušivý a nepř́íjemný element, je pozorovatel ve výuce pro učitele přijatelnější. Bylo použito pozorování výuky s následným záznamem do pozorovacího archu Murphyové $(1997)^{2}$, protože obsahuje kategorie zjistitelné pouhým pozorováním, a to jako jediné metody získávání informací o didaktickém zpracování učiva a jeho zprostředkování žákům. Tento systém obsahuje 18 konstruktivistických znaků výuky, u nichž se zaznamenává přítomnost respektive nepř́itomnost ve sledované výuce. Originální arch byl po překladu do českého jazyka ještě doplněn o kontrolní položku „důkaz“, do které se vypisovaly konkrétní jevy, které prokazovaly prrítomnost či nepř́itomnost sledovaného znaku ve výuce. Pozorována byla jedna vyučovací hodina prvouky, přičemž učitelky nebyly informovány o obsahu záznamového archu.

\footnotetext{
${ }^{2}$ Výčet všech konstruktivistických znaků Ize nalézt v př́ispěvku „Učí učitelé konstruktivisticky?" na konferenci ČAPV 2007.
} 
Pro získání dat od žáků bylo výhodné využít kresby, protože bylo již ve výzkumech realizovaných v minulosti dokázáno, že tímto způsobem lze od žáků získat data poměrně snadno. Tato projektivní metoda je velmi efektivní zvláště u malých žákủ, kteří dávají kresbě přednost před psaným projevem. Reiss a Tunnicliffová (2001, s. 384) upozorňují zejména na lepší přístupnost metody pro žáky, kteří nemají takovou jazykovou výbavu, aby byli schopni popsat, at' ústně, nebo písemně, co si představují. Jako nejvýhodnější z několika hledisek se pro zjištování prekonceptu o trávicí soustavě člověka jevilo použití pracovního listu s testovým úkolem s otevřenou odpovědí, jehož zadání znělo: „Nakresli, kudy prochází naším tělem potrava“"3, a siluetou postavy člověka, do které měli žáci svou představu zakreslit. $\mathrm{Z}$ metodologického hlediska se $\mathrm{v}$ podstatě jedná o typ testu, kterým se zjišt'uje úroveň žákovy znalosti, v tomto př́padě stav a modifikace prekonceptu. Výsledky žáků byly kategorizovány do sedmi skupin podle správnosti odpovědí - nejlepší výsledky byly zařazeny do kategorie č. 1, nejhorší pak do kategorie č. 7 .

Při vyhodnocování výzkumných zjištění se komparovaly dvě skupiny dat - výsledky žáků, u nichž byl pozorován určitý konstruktivistický znak, $\mathrm{s}$ těmi, u kterých konkrétní konstruktivistický znak výuky pozorován nebyl. Pro zjištění vztahů mezi daty sebranými od žáků a daty sebranými od učitelů byl vypočítán nejprve Spearmanův koeficient pořadové korelace, který určuje těsnost souvislostí mezi zkoumanými jevy (Chráska, 2007, s. 103-105). Pro zjištění významnosti vztahů mezi sebranými daty byl použit Studentův t-test, který porovnává aritmetické průměry zkoumaných dat (Chráska, 2007, s. 122-124). Poslední z použitých statistických metod je Fisherův-Snedecorův F-test. Ten zjišt'uje, jak velký je rozptyl mezi daty ve zkoumaném souboru (Chráska, 2007, s. 128). Výsledkem je velikost rozptylu dat ve zkoumaném souboru na určité hladině významnosti. Veškeré statistické analýzy byly zpracovány pomocí počítačového programu Statistica a převedeny do tabulek a grafů.

\section{Vyhodnocení sebraných dat}

Prezentovaný výzkum řeší problematiku vlivu konstruktivistických znaků na prekoncepty žáků. Proto hlavní výzkumná otázka zní: Ovlivňuje přitomnost konstruktivistických znakù ve výuce kvalitu a proměnu prekonceptu žáki̊? V tabulce č. 1 jsou znázorněny výsledky výzkumu pro situace, kdy byl prokázán vliv konstruktivistického znaku výuky na výsledky žáků v některé z fází výuky nebo na rozvoj kvality prekonceptu mezi jednotlivými fázemi, a to pozitivní i negativní. Bylo zjištěno, že přítomnost některých konstruktivistických znaků ve výuce ovlivňuje kvalitu prekonceptů i jejich proměnu. Zaznamenán byl vliv pozitivní i negativní, a to $\mathrm{v}$ obou př́ípadech. Pozitivně na kvalitu prekonceptu působí metoda zkoumání ${ }^{4}$ nebo využití metakognitivních strategii ${ }^{5}$, negativně zase snaha učitelů přiblížit žákům realitu světa pomocí autentických činností ${ }^{6}$ nebo propojení nových pojmů se známým kontextem ${ }^{7}$. Na vývoj prekonceptu mají pozitivní vliv kooperativní činnosti ze strany učitele ${ }^{8}$ i ze strany žáků9, ale také odkazování na vztahy mezi známými pojmy, různými vyučovacími předměty a novým učivem ${ }^{10}$. Negativně na vývoj prekonceptu působila metoda zkoumání ${ }^{11}$.

\footnotetext{
${ }^{3}$ Inspirováno pracovním sešitem Prvouka pro 3. ročník ZŠ (Vyskočilová a kol., 1995).

${ }^{4} \mathrm{~V}$ tabulce č. 1 pod číslem 12.

${ }^{5} \mathrm{~V}$ tabulce č. 1 pod číslem 4.

${ }^{6} \mathrm{~V}$ tabulce č. 1 pod číslem 6.

${ }^{7} \mathrm{~V}$ tabulce č. 1 pod číslem 14.

${ }^{8} \mathrm{~V}$ tabulce č. 1 pod číslem 15.

${ }^{9} \mathrm{~V}$ tabulce č. 1 pod číslem 8.

${ }^{10} \mathrm{~V}$ tabulce č. 1 pod číslem 14.
} 


\section{Diskuse}

Důvodů pro prezentovaná protikladná zjištění může být hned několik. Hlavním důvodem může být nereprezentativnost vzorku a jistý samovýběr (učitelé museli s výzkumem souhlasit), který byl konečným klíčem pro nominaci respondentů zařazených do výzkumu. $\mathrm{Z}$ toho důvodu také není možné výsledky generalizovat a vztáhnout je na celou populaci učitelů na prvním stupni základních škol v České republice. Je možné se domnívat, že by se na větším vzorku výsledky přiklonily $\mathrm{k}$ některým $\mathrm{z}$ pólů daleko výrazněji, než tomu bylo $\mathrm{v}$ mém př́padě. Je tu i možnost nesprávné aplikace konstruktivistických metod (De Vriesová 2002, s. 26), respektive metod obecně, na které žáci nemuseli být zvyklí a učitelkám mohlo působit problém je plně zvládnout. Výsledky jiných výzkumů (napřr. Newmann, Marks, \& Gamoran, 1996) zdůrazňovaly důležitost poctivé přípravy a dodržování pravidel použitých metod, aby bylo možné dosáhnout požadovaných cílů. Tím mohl zprostř̌edkovaně ovlivnit výsledky výzkum samotný, protože učitelky mohly učivo probrat jinak, než byli žáci zvyklí. A konečně, obecně se, tvrdí, že různí učitelé preferují odlišné styly výuky a různí žáci mají odlišné styly učení. Mé výsledky mohou být důkazem toho, že tomu tak skutečně je, a nelze tedy jednoznačně určit, zda k lepším výsledkům žáků vede výuka podle zásad tradičních nebo konstruktivistických.

\section{Závěr}

V každém př́padě lze ale konstatovat, že pozitivní výsledky konstruktivistického pojetí byly nalezeny v podobě aplikace metod kooperativního učení, což je model založený na spolupráci žáků mezi sebou. Zprostředkuje sociální kontakt a setkání s rủznými názory, které je třeba pro úspěch v práci prokonzultovat. Kromě toho byl zaznamenán i pozitivní vliv utváření systémů vztahů mezi známými a neznámými pojmy nebo vlastního zkoumání a objevování nových věcí. Výzvou pro další zkoumání může být rozšiřrení výzkumného vzorku tak, aby se dalo hovořit o reprezentativnosti, tedy pokusit se dokázat, že některý z prezentovaných modelů má více či méně pozitivní vliv na prekoncepty žáků než ten druhý. Zajímavý by byl také experiment s proškolenými učiteli, schopnými aplikovat konstruktivistické znaky ve větší míře, který by dovolil porovnat výsledky konstruktivistické a tradiční výuky. Přispělo by to bezesporu do rozsáhlé celosvětové diskuse na téma účinnosti tradičních, respektive jakkoli inovovaných alternativních koncepcí vzdělávání. Prozatím je možné spokojit se s tím, že na základě tohoto výzkumu o výrazném efektu konstruktivistické výuky na prekoncepty žáků hovořit nelze.

\footnotetext{
${ }^{11} \mathrm{~V}$ tabulce č. 1 pod číslem 12
} 
Tabulka 1

Vliv jednotlivých pozorovaných konstruktivistických znaků na výsledky žáki̊

\begin{tabular}{|c|c|c|c|c|c|c|c|c|c|c|}
\hline \multirow{2}{*}{$\begin{array}{c}\text { fáze } \\
\text { výzk. } \\
\text { č. kon. } \\
\text { znaku }\end{array}$} & \multicolumn{2}{|c|}{$\begin{array}{c}\text { kvalita } \\
\text { prekonceptu }\end{array}$} & \multicolumn{2}{|c|}{$\begin{array}{l}\text { rozptyl kvality } \\
\text { prekonceptù }\end{array}$} & \multicolumn{3}{|c|}{ proměna prekonceptů } & \multicolumn{3}{|c|}{\begin{tabular}{|c} 
rozptyl v míře proměny \\
prekonceptu
\end{tabular}} \\
\hline & fáze 2 & fáze 3 & fáze 2 & fáze 3 & \begin{tabular}{|c} 
fáze 1 \\
fáze 2
\end{tabular} & $\begin{array}{r}\text { fáze } 1- \\
\text { fáze } 3\end{array}$ & $\begin{array}{l}\text { fáze } 3- \\
\text { fáze } 2\end{array}$ & $\begin{array}{c}\text { fáze } 1- \\
\text { fáze } 2\end{array}$ & $\begin{array}{r}\text { fáze } 1- \\
\text { fáze } 3\end{array}$ & $\begin{array}{r}\text { fáze } 3- \\
\text { fáze } 2\end{array}$ \\
\hline 4 & & & + & + & & & & & & \\
\hline 6 & & - & & & & & & & & \\
\hline 8 & & & & & + & + & & & & \\
\hline 12 & & + & + & + & - & & & + & & \\
\hline 13 & & & & & & & & + & & + \\
\hline 14 & - & & & & - & & + & & & \\
\hline 15 & & & & & + & + & & & & \\
\hline 16 & - & - & - & - & & & & & & - \\
\hline
\end{tabular}

\section{Literatura}

De Vries, R. (2002). What does research on construcivist education tell us about effecting schooling? Dostupné z http://www.education.uiowa.edu/iae/iae-z-op-devries-1-5.pdf

Einsiedler, W. (2005). Lehr-lern-konzepte fur grundschule. In W. Einsiedler et al. (Eds.), Handbuch Grundschulpadagogik und Grundschuldidaktik (pp. 373-385). Bad Heilbrunn: Julius Klinkhardt.

Chráska, M. (2007). Metody pedagogického výzkumu. Praha: Grada Publishing.

Korcová, K. (2007). Učí učitelé konstruktivisticky? In R. Jandová (Ed.), Svět výchovy a vzdělávánív reflexi současného pedagogického výzkumu. (pp. 1-10). České Budějovice: JČU v Českých Budějovicích. [CD-ROM]

Klafki, W. (1967). Studie k teorii vzdělání a didaktice. Praha: SPN.

Murphy, E. (1997). Constructivism. From philosophy to practice. Dostupné z http://www.cdli.ca/ elmurphy/emurphy/cle.html

Newmann, F. M., Marks, H. M., \& Gamoran, A. (1996). Authentic pedagogy and student performance. American Journal of Education, 104(4), 280-312.

Reiss, M. J., \& Tunnicliff, S. D. (2001). Students' understandings of human organs and organs systems. Research in Science Education, 31(3), 383-399.

Vyskočilová, E. at al. (1995). Prvouka pro 3. ročník základni i obecné školy. Pozorujeme, ptáme se, poznáváme. Praha: Portál.

\section{Kontakt}

Mgr. Kateřina Korcová, Ph.D.

Základní škola a mateřská škola, Otnice, okres Vyškov

Školní 352, 68354 Otnice

Masarykova univerzita

Filozofická fakulta, Ústav pedagogických věd

A. Nováka 1, 60200 Brno

e-mail: korcova@phil.muni.cz 


\section{Bibliografické údaje}

Korcová, K. (2011). Proměna prekonceptu žáků 3. tř́ídy základní školy. In T. Janík, P. Knecht, \& S. Šebestová (Eds.), Smišený design v pedagogickém výzkumu: Sborník přispěvki z 19. výroční konference České asociace pedagogického výzkumu (s. 338-343). Brno: Masarykova univerzita.

Dostupné z: http://www.ped.muni.cz/capv2011/sbornikprispevku/korcova.pdf doi: 10.5817/PdF.P210-CAPV-2012-29 